\title{
BIDIL: A RACE-TARGETED DRUG FOR BLACK AMERICAN'S ONLY
}

\author{
NAVEEN CHANDRA TALNIYA* \\ Department of Chemistry, School of Chemical Engineering \& Physical Sciences, Lovely Professional University, Punjab - 144 411, India. \\ Email: naveen_talniya@yahoo.com
}

Received: 16 May 2017, Revised and Accepted: 13 July 2017

\begin{abstract}
It has been noted that pharma research toward race-targeted medicine and it criticism is going on simultaneously over the past few years. Some argued that drugs specifically target to cure particular racial groups could play a vital role against racial disparities in health. While others claimed that race-targeted medicine inappropriately treats race as a biological reason for racial disparities when broader social and environmental factors may offer better descriptions. Much of this debate includes the Food and Drug Administration's approval of drug BiDil in 2005, which became the first drug to be marked for a specific racial group black Americans who suffers from heart failure (HF). This controversial drug was declared failed due to less attention of physician's as well as its high cost in market. The highlighted part of this review is that besides much criticism still this drug prescribed by majority of physicians. Moreover, BiDil is not only one which is race specific but also there are more drugs which have been claimed to have different effects in different racial or ethnic groups.
\end{abstract}

Keywords: Race, Black Americans, Food and Drug Administration, HF, BiDiL.

(C) 2017 The Authors. Published by Innovare Academic Sciences Pvt Ltd. This is an open access article under the CC BY license (http://creativecommons. org/licenses/by/4. 0/) DOI: http://dx.doi.org/10.22159/ajpcr.2017.v10i11.20022

\section{INTRODUCTION}

The Centers for Disease Control and Prevention (CDC) latest report revealed that the pattern of life expectancy in the United States (U.S.) has actually been one of progressive improvement for all races of people since 1900 (Fig. 1). Their life expectancy at birth increased to 78.8 years in 2014 which was 70.8 years in 1970 (Fig. 1). For the white Americans, life expectancy raised by $10 \%$ (from 71.7 to 79.0 years) and $18 \%$ (from 64.1 to 75.6 years) for the black Americans. Among the significant racesex groups, white women's continued to have the greatest life expectancy at birth (81.4 years), followed by black women (78.4 years), white men (76.7 years), as well as black men (72.5 years) (Fig. 2) [1].

The CDC report clearly indicates that white Americans could expect to live 3.4 years longer than black Americans under current mortality patterns, and this gap is due to higher death rate that includes heart disease, cancer, homicide, diabetes, and perinatal conditions.

Chronic diseases are the dominant contributors to the global burden of disease, and cardiovascular disease (CVD) is the largest contributor to worldwide disease which includes coronary heart disease (CHD) is a major cause of death and disability in developed countries [2]. Undoubtedly, CVD is the No. 1 killer of all Americans, and also stroke is the fourth-leading reason of fatality. Individuals of all ages, genders, races, and ethnic backgrounds are affected. Although treatments have actually progressed for coronary heart problem within the past two decades, black Americans continue to have double the risk of fatal coronary heart problem and remain more likely compared to whites to die from heart-related diseases (Fig. 3) [1,3].

In 2005, the U.S. Food and Drug Administration (FDA) approved BiDil drug to treat African- Americans with congestive HF. As it was approved due to the positive result seen in African-American Heart Failure Trial, but the drug was under controversy from the day of approval. The present review deals with the approval history of BiDil, its criticism, and the current status among physicians.

\section{RACE-TARGETED MEDICINE AND BIDIL}

Rates of in the US have consistently decreased since the 1970s for all races of people both death certificate data, and evidence suggest a steeper decline in acute CHD mortality between 2000 and 2008 for whites than for blacks, widening a long-standing disparity [4]. Health disparities, as defined by the U.S. health-care system refers to population specific differences in the presence of disease, health outcomes, quality of health care, and access to health-care services that exist across racial and ethnic groups [5]. Due to these low health indicators, it would presume that minorities, specifically black Americans, would take actions to enhance their health. However, the opposite holds true. Black Americans are considered as distrustful of clinical research, which subsequently influences health results and quality of life. It has been reported [6] that black American community leaders capitalized on an opportunity to bring attention to black American health issues with respect to the drug BiDil, an HF drug. BiDil is connected to treat healthcare disparities because it specifically targets the black American population who disproportionately struggle with heart disease. To reduce health disparities in racial populations, drug marketing research, is one mechanism. Advertising and marketing is an effective tool that not only advances the pharmaceutical drug's profit margin but also additionally educates the minority population on the benefits of seeking treatment. Race-targeted medication is extremely debated and noted as a result of such targeted race medication may advance the treatment process at one hand, however, on the other hand, it may negatively uphold stereotypes and ideologies of certain groups.

\section{CONTROVERSIAL HISTORY OF BIDIL AND ITS FDA APPROVAL}

The drug BiDil, a combination of two generic medications - hydralazine hydrochloride and isosorbide dinitrate (hydralazine/ISDN, Fig. 4) in a single tablet, has an appealing past despite its favorable results in the black American community. BiDil was patented by cardiologists Jay Cohn and Peter Carson in 1989 for congestive HF. The initial study of BiDil failed to receive the FDA approval. The first FDA application was submitted in 1997, however, the results failed to show enough statistical efficacy for a multiracial population with CVD. On the recommendation of members of FDA's advisory committee, NitroMed pharmaceuticals reexamined the clinical trial data along racial lines.

Under the trial [7], a total of 1,050 men and women, who self-identified as black Americans, were enrolled with the New York Heart Association over $85 \%$ class III HF at 169 centers in the US. All black patients had 
stable symptomatic cardiac arrest. They were needed to have left ventricular ejection fraction (LVEF) $\leq 35 \%$ or left ventricular internal diastolic dimension $>2.9 \mathrm{~cm} / \mathrm{m}^{2}$ plus LVEF $<45 \%$. These individuals

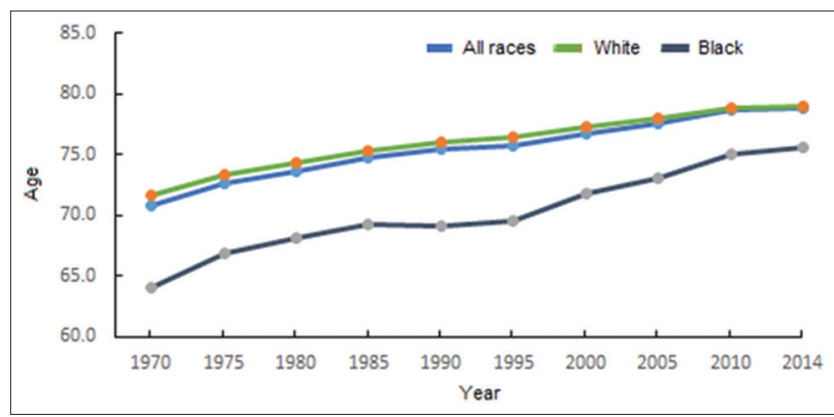

Fig. 1: Life expectancy, by race: United States, 1970-2014. Source: Centers for Disease Control and Prevention

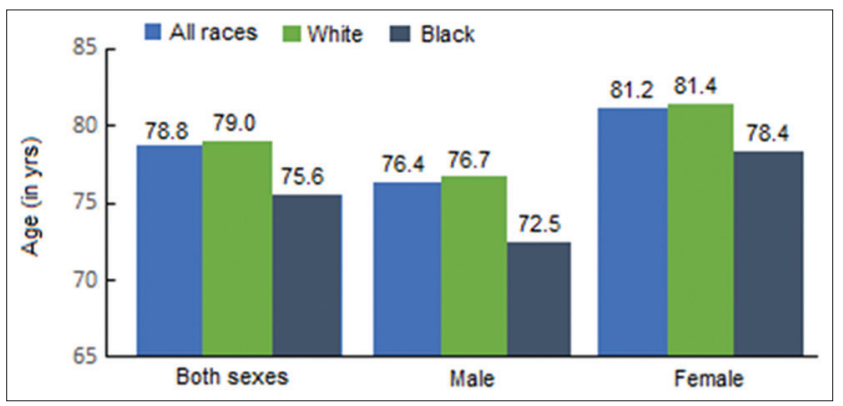

Fig. 2: Life expectancy at birth, by race, and sex: United States. Source: Centers for Disease Control and Prevention

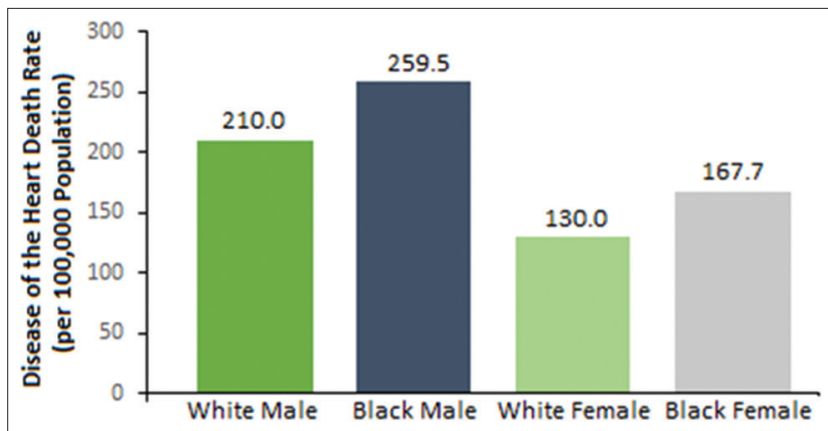

Fig. 3: Heart diseases death rate, by race, and sex: United States. Source: Centers for Disease Control and Prevention<smiles></smiles><smiles>O=[N+]([O-])O[C@H]1CO[C@H]2[C@@H]1OC[C@@H]2[N+](=O)[O-]</smiles>

hydralazine hydrochloride

is os orbide dinitrate

Fig. 4: BiDil, combination of two generic medications were maintained on stable background therapy and randomized to BiDil $(n=518)$ or placebo $(n=532)$. They were treated for up to 18 months initiated with three doses of BiDil (hydralazine [37.5 mg]/ISDN [20 mg]) daily and titrated to a target dose of $(75 / 40) \mathrm{mg}$ three times daily or to the maximum tolerated dose. In the randomized population, with a mean age of 57 years was $60 \%$ of male having $1 \%$ NYHA class II, $95 \%$ NYHA class III, and $4 \%$ NYHA class IV. They were generally treated with standard therapy for HF including diuretics (94\%), $\beta$-blockers (87\%), angiotensin-converting enzyme inhibitors (ACE-I; 78\%), angiotensin II receptor blockers (ARBs; 28\%), either ACE-I or ARB (93\%), digitalis glycosides (62\%), and aldosterone antagonists (39\%) [6].

The primary end point was a composite score consisting of all-cause mortality and first hospitalization for HF. The trial was ended early to avoid additional deaths among patients receiving a placebo. With a median follow-up of 12 months, fixed dose of BiDil showed statistically significant $43 \%$ reduction in all-cause mortality ( $p=0.012$, Table 1 ) [7]. The primary end point also showed a significant effect toward BiDil ( $p \leq 0.021$, Table 1) and also decreased the number of hospitalizations by $39 \%$ as well as length of hospital stay compared with standard therapy alone for $\mathrm{HF}(\mathrm{p}<0.001$; Table 1$)[8]$

\section{CRITICISMS OF BIDIL}

It was not surprised that approval of BiDil, specifically for black Americans led to dialogs in both the scientific and biomedical fields. Critics augmented that a drug only for blacks would prevent its use in other individuals who might benefit, and that race is at best a crude marker for underlying hereditary and physical variations [9]. An editorial on racial profiling in medicine pointed that "race is a social construct, not a scientific classification. After 400 years of social disruption, geographic dispersion, and genetic intermingling, there are no alleles that define the black people of North America as a unique population or race [10]." The drug was criticized politically, commercially, and scientifically.

In the political fields, the FDA is criticized for approving the drug BiDil because the drug is targeted for a specific population, black Americans. Historically, the FDA has discouraged clinical research practices that take advantage of marginalized groups. It is argued that the FDA's decision "may be a setback to scientific discourse on therapeutics and may be specifically deleterious to efforts aimed at addressing disparities in health and health care [11]. BiDil has further been criticized for exploiting the black American community for corporate profit and to a poor precedent of racial segregation in medicine [6]. Even more, the drug was marketed as a race-specific treatment, but in reality, there was evidence that the drug was effective across racial lines [12].

Commercially, the drug also criticized for its price because the generic drug was priced significantly lower at approximately $\$ 1.50-\$ 3.00$ while BiDil was priced at $\$ 5.40-\$ 10.80$ per day for the treatment. It would seem that if the goal were to increase access to health care and decrease disparities in the provision of health, the drug manufacturer would have priced the drug in a range that was affordable for the population. Despite the discounts and gratuitous availability of the drug for certain groups, cardiologists argued that the drug cost exceeded many patients' financial ability to pay [13]. However, accounting for insurance and other factors it is arguable whether the cost of the drug is commercially exploiting the black American population. BiDil was not only the single drug which has shown better

Table 1: Results of A-HeFT (intent-to-treat population)

\begin{tabular}{|c|c|c|c|c|}
\hline End point & BiDil group $(n=518)$ & Placebo group $(n=532)$ & Hazard ratio $(95 \% \mathrm{CI})$ & Risk reduction \\
\hline Composite score & $-0.16 \pm 1.93$ & $-0.47 \pm 2.04$ & - & 0.021 \\
\hline Death from any cause & $6.20 \%$ & $10.20 \%$ & $0.57(0.37-0.89)$ & $43 \%(\mathrm{p}=0.012)$ \\
\hline First hospitalized for heart failure & $16.40 \%$ & $24.40 \%$ & $0.61(0.46-0.80)$ & $39 \%(\mathrm{p} \leq 0.012)$ \\
\hline
\end{tabular}


response to a specific race people. There are many medicines or their combinations have been also claimed to have differences in either safety or, more commonly, efficacy among racial or ethnic groups. However, these claims are universally controversial $[10,14,15]$, and there is no general opinion on how important race or ethnicity is in determining drug response [16]. There is a compilation of drugs (Table 2) to have different effects in different racial or ethnic groups on for an overview of the relationship between racial or ethnic on the basis of literature [17].

There are literatures available which reveal that several combination products have shown to be effective in the treatment of type 2 diabetes also [52]. Glucovance is an example of a combination of glyburide and metformin which was proven to reduce fasting plasma glucose by $50-60 \mathrm{mg} / \mathrm{dl}$. Other combinations include Metaglip (glipizide/ metformin) and Avandamet (rosiglitazone/metformin and Duetact (pioglitazone/glimepiride) [53-55].

\section{CURRENT STATUS OF BIDIL AMONG PHYSICIAN'S}

The guidelines of the American College of Cardiology as well as the American Heart Association and Heart Failure Society of America recommending BiDil to self-identified black Americans. This drug could be prescribed by the physician's to black Americans, as a complement to the standard therapy, for the treatment of HF, to improve their survival, length of time to hospitalization, and improve patient-reported functional status [56,57]. However, the drug BiDil is underutilized by the physician's and prescribed to less than $20 \%$ of black Americans [58]. Further, it has been noted that individual adherence to this regimen is generally poor because of regular negative responses, including migraine, dizziness, and gastrointestinal problems along with the large number of tablets individuals have to take $[8,9,57]$.

Beside all the controversies, the drug BiDil is still existing in the market and recommended by physician's. A recent study [59] presents an analysis of the factors influencing prescription of BiDil by physician's and investigated whether exposure to the controversies behind the drug has an impact on their therapeutic judgments. Study based on the two groups of physician's where one group receiving information about the controversy over BiDil. The outcome of the study reveals that $27 \%$ of the medical professionals are using individual's race as a major factor in making treatment decisions. While, 33\% reported the ineffectiveness of standard treatments, $25 \%$ the seriousness of the disease, and $15 \%$ other undefined factors as a primary determining criteria in recommending BiDil. On the other hand, $68 \%$ of physician's reported that they were not familiar with any controversy surrounding BiDil. In general, physicians are recommending BiDil drug and want to recommend more to black patients compare to white-patients.

\section{CONCLUSION}

Having strong clinical trial proofs as well as basic scientific information clearly indicates the benefits of BiDil are in favor of self-identified black patients but still the proper utilization of the drug remains poor. There is a need of collective efforts by the scientific community, physician's, and public health officials for the better future of the BiDil. They should recognize and execute strategies to overcome patient and service provider barriers to appropriate evidence-based care for HF, specifically in black Americans, to conquer unacceptable disparities in HF morbidity and also mortality.

The discovery of BiDil is a sign of hope to resolve possible racial differences in clinical response to medicines and narrowing the unequal access to clinical services. The development of race-targeted medicines highlights potentially distinctive clinical demands in a racial community. Due to the historical injustices surrounding black Americans and scientific research, the development of BiDil needs to be considered as not only a drug development but also as a socially progressive step that could raise minority involvement in research.
Table 2: Response of drugs to different racial or ethnic groups

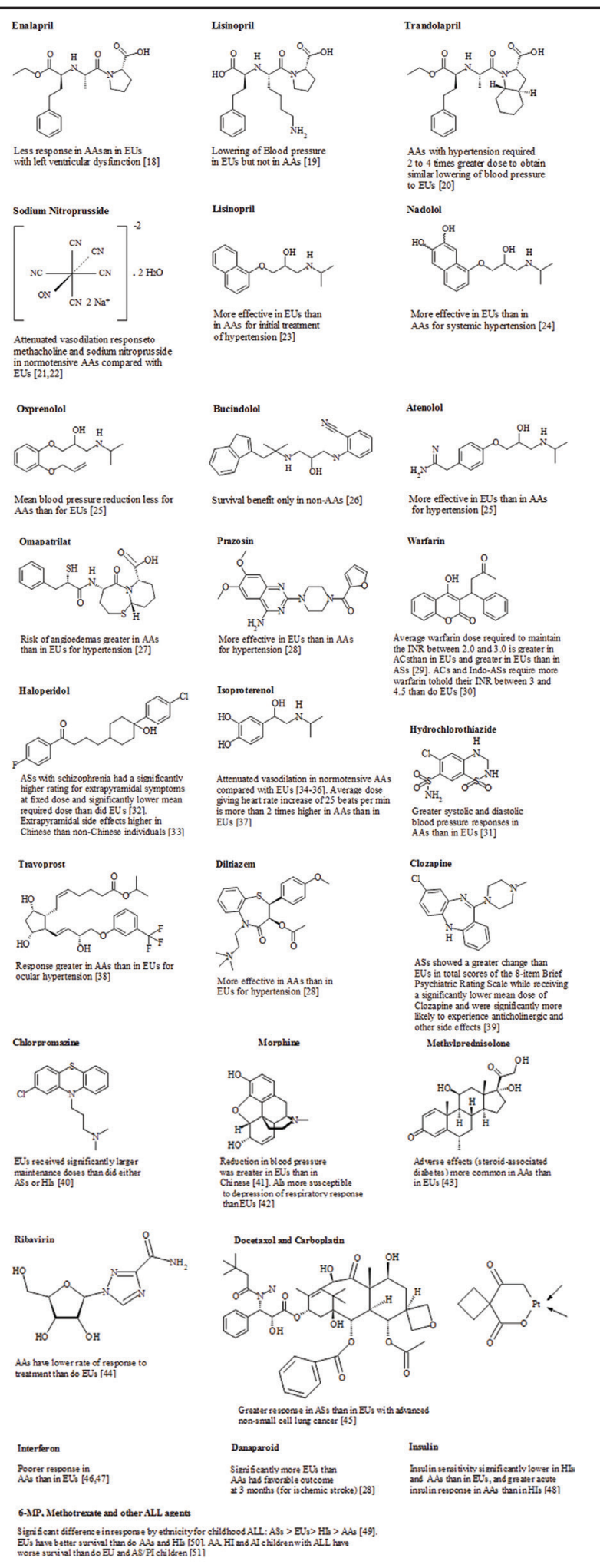

Racial or ethnic groups: AA: African American, AC: Afro-Caribbean,

AI: American Indian and Alaskan Native, AS: Asian, EU: European ancestry, HI: Hispanic, PI: Pacific Islander, ALL: Acute lymphoblastic leukemia, INR: International Normalized Ratio (for blood clotting time)

Scientifically, there are widespread criticisms to the use of race-targeted medicine; the more important question to explore is whether racebased medicine can reduce health disparities. Medical research should 
by no means perpetuate stereotypes and racism, but if race-targeted medicine can close the gap in the health indicators that relate to access to care, perhaps race-based medicine is a solution and not an actual problem.

\section{ACKNOWLEDGMENTS}

This research did not receive any specific grant from funding agencies in the public, commercial, or not-for-profit sectors. Further, I acknowledge Lovely Professional University for providing the required facilities to carry out the presented study.

\section{REFERENCES}

1. National Institutes of Health. National Center for Health Statistics, Health, United States, 2015: With Special Feature on Racial and Ethnic Health Disparities. Hyattsville, MD: National Institutes of Health; 2015. p. 107

2. Priya JK, Balambigai MS, Sariga N, Sathya M, Andhuvan G. Development and validation of patient information leaflet for heart attack patients. Int J Pharm Pharm Sci 2016;8(8):381-3.

3. Roger VL, Go AS, Lloyd-Jones DM, Benjamin EJ, Berry JD, Borden WB, et al. Executive summary: Heart disease and stroke statistics--2012 update: A report from the American Heart Association. Circulation 2012;125(1):188-97.

4. Safford MM, Brown TM, Muntner PM, Durant RW, Glasser S, Halanych $\mathrm{JH}$, et al. Association of race and sex with risk of incident acute coronary heart disease events. JAMA 2012;308(17):1768-74.

5. Riley WJ. Health disparities: Gaps in access, quality and affordability of medical care. Trans Am Clin Climatol Assoc 2012;123:167-72.

6. Yu JH, Goering S, Fullerton SM. Race-based medicine and justice as recognition: Exploring the phenomenon of BiDil. Camb Q Healthc Ethics 2009;18(1):57-67.

7. Taylor AL, Ziesche S, Yancy C, Carson P, D'Agostino R Jr, Ferdinand K, et al. Combination of isosorbide dinitrate and hydralazine in blacks with heart failure. N Engl J Med 2004;351(20):2049-57.

8. Taylor AL, Ziesche S, Yancy CW, Carson P, Ferdinand K, Taylor M, et al. Early and sustained benefit on event-free survival and heart failure hospitalization from fixed-dose combination of isosorbide dinitrate/ hydralazine: Consistency across subgroups in the African-American Heart Failure Trial. Circulation 2007;115(13):1747-53.

9. Cole RT, Kalogeropoulos AP, Georgiopoulou VV, Gheorghiade M, Quyyumi A, Yancy C, et al. Hydralazine and isosorbide dinitrate in heart failure: Historical perspective, mechanisms, and future directions. Circulation 2011;123(21):2414-22.

10. Schwartz RS. Racial profiling in medical research. N Engl J Med 2001;344(18):1392-3.

11. Bibbins-Domingo K, Fernandez A. BiDil for heart failure in black patients: Implications of the U.S. Food and Drug Administration approval. Ann Intern Med 2007;146(1):52-6.

12. Kahn J, Sankar P. Being specific about race-specific medicine. Health Aff (Millwood) 2006;25(5):w375-7.

13. Stephanie S. Maker of Heart Drug Intended for Blacks Bases Price on Patients' Wealth, New York Times (1923-Current File) C3; 2005.

14. Cooper RS, Kaufman JS, Ward R. Race and genomics. N Engl J Med 2003;348(12):1166-70

15. Burchard EG, Ziv E, Coyle N, Gomez SL, Tang H, Karter AJ, et al. The importance of race and ethnic background in biomedical research and clinical practice. N Engl J Med 2003;348(12):1170-5

16. Tate SK, Goldstein DB. Will tomorrow's medicines work for everyone? Nat Genet 2004;36 11 Suppl: S34-42.

17. Bjornsson TD, Wagner JA, Donahue SR, Harper D, Karim A, Khouri MS, et al. A review and assessment of potential sources of ethnic differences in drug responsiveness. J Clin Pharmacol 2003;43(9):943-67.

18. Exner DV, Dries DL, Domanski MJ, Cohn JN. Lesser response to angiotensin-converting-enzyme inhibitor therapy in black as compared with white patients with left ventricular dysfunction. N Engl J Med 2001;344(18):1351-7.

19. Weir MR, Reisin E, Falkner B, Hutchinson HG, Sha L, Tuck ML. Nocturnal reduction of blood pressure and the antihypertensive response to a diuretic or angiotensin converting enzyme inhibitor in obese hypertensive patients. TROPHY Study Group. Am J Hypertens 1998;11:914-20.

20. Weir MR, Gray JM, Paster R, Saunders E. Differing mechanisms of action of angiotensin-converting enzyme inhibition in black and white hypertensive patients. The Trandolapril Multicenter Study Group.
Hypertension 1995;26(1):124-30

21. Stein CM, Lang CC, Nelson R, Brown M, Wood AJ. Vasodilation in black Americans: Attenuated nitric oxide-mediated responses. Clin Pharmacol Ther 1997;62(4):436-43.

22. Rosenbaum DA, Pretorius M, Gainer JV, Byrne D, Murphey LJ, Painter CA, et al. Ethnicity affects vasodilation, but not endothelial tissue plasminogen activator release, in response to bradykinin. Arterioscler Thromb Vasc Biol 2002;22(6):1023-8.

23. Cubeddu LX, Aranda J, Singh B, Klein M, Brachfeld J, Freis E, et al. A comparison of verapamil and propranolol for the initial treatment of hypertension. Racial differences in response. JAMA 1986;256(16):2214-21.

24. Efficacy of nadolol alone and combined with bendroflumethiazide and hydralazine for systemic hypertension. Am J Cardiol 1983;52(10):1230-7.

25. Friedman B, Gray JM, Gross S, Levit SA. United States experience with oxprenolol in hypertension. Am J Cardiol 1983;52(9):43D-8.

26. Beta-Blocker Evaluation of Survival Trial Investigators, Eichhorn EJ, Domanski MJ, Krause-Steinrauf H, Bristow MR, Lavori PW. A trial of the beta-blocker bucindolol in patients with advanced chronic heart failure. N Engl J Med 2001;344(22):1659-67.

27. Zanchi A, Maillard M, Burnier M. Recent clinical trials with omapatrilat: New developments. Curr Hypertens Rep 2003;5(4):346-52.

28. Cushman WC, Reda DJ, Perry HM, Williams D, Abdellatif M, Materson BJ. Regional and racial differences in response to antihypertensive medication use in a randomized controlled trial of men with hypertension in the United States. Department of Veterans Affairs Cooperative Study Group on Antihypertensive Agents. Arch Intern Med 2000;160(6):825-31.

29. Blann A, Hewitt J, Siddiqui F, Bareford D. Racial background is a determinant of average warfarin dose required to maintain the INR between 2.0 and 3.0. Br J Haematol 1999;107(1):207-9.

30. Blann A, Bareford D. Ethnic background is a determinant of average warfarin dose required to maintain the INR between 3.0 and 4.5 . J Thromb Haemost 2004;2(3):525-6.

31. Chapman AB, Schwartz GL, Boerwinkle E, Turner ST. Predictors of antihypertensive response to a standard dose of hydrochlorothiazide for essential hypertension. Kidney Int 2002;61(3):1047-55.

32. Lin KM, Poland RE, Nuccio I, Matsuda K, Hathuc N, Su TP, et al. A longitudinal assessment of haloperidol doses and serum concentrations in Asian and Caucasian schizophrenic patients. Am J Psychiatry 1989;146(10):1307-11.

33. Jann MW, Chang WH, Davis CM, Chen TY, Deng HC, Lung FW, et al. Haloperidol and reduced haloperidol plasma levels in Chinese vs. NonChinese psychiatric patients. Psychiatry Res 1989;30(1):45-52.

34. Watkins LL, Dimsdale JE,Ziegler MG. Reduced beta2-receptor mediated vasodilation in African Americans. Life Sci 1995;57(15):1411-6.

35. Cardillo C, Kilcoyne CM, Cannon RO $3^{\text {rd }}$, Panza JA. Attenuation of cyclic nucleotide-mediated smooth muscle relaxation in blacks as a cause of racial differences in vasodilator function. Circulation 1999;99(1):90-5

36. Lang CC, Stein CM, Brown RM, Deegan R, Nelson R, He HB, et al. Attenuation of isoproterenol-mediated vasodilatation in blacks. N Engl J Med 1995;333(3):155-60.

37. Johnson JA, Burlew BS, Stiles RN. Racial differences in betaadrenoceptor-mediated responsiveness. J Cardiovasc Pharmacol 1995;25(1):90-6

38. Netland PA, Robertson SM, Sullivan EK, Silver L, Bergamini MV, Krueger $\mathrm{S}$, et al. Response to travoprost in black and nonblack patients with open-angle glaucoma or ocular hypertension. Adv Ther 2003;20(3):149-63.

39. Matsuda KT, Cho MC, Lin KM, Smith MW, Young AS, Adams JA. Clozapine dosage, serum levels, efficacy, and side-effect profiles: A comparison of Korean-American and Caucasian patients. Psychopharmacol Bull 1996;32(2):253-7.

40. Collazo Y, Tam R, Sramek J, Herrera J. Neuroleptic dosing in Hispanic and Asian Inpatients with schizophrenia. Mt Sinai J Med 1996;63(56):310-3.

41. Zhou HH, Sheller JR, Nu H, Wood M, Wood AJ. Ethnic differences in response to morphine. Clin Pharmacol Ther 1993;54(5):507-13.

42. Cepeda MS, Farrar JT, Roa JH, Boston R, Meng QC, Ruiz F, et al. Ethnicity influences morphine pharmacokinetics and pharmacodynamics. Clin Pharmacol Ther 2001;70(4):351-61.

43. Tornatore KM, Biocevich DM, Reed K, Tousley K, Singh JP, Venuto RC. Methylprednisolone pharmacokinetics, cortisol response, and adverse effects in black and white renal transplant recipients. Transplantation 1995;59(5):729-36. 
44. Muir AJ, Bornstein JD, Killenberg PG; Atlantic Coast Hepatitis Treatment Group. Peginterferon alfa-2b and ribavirin for the treatment of chronic hepatitis $\mathrm{C}$ in blacks and non-Hispanic whites. N Engl J Med 2004;350(22):2265-71

45. Millward MJ, Boyer MJ, Lehnert M, Clarke S, Rischin D, Goh BC, et al. Docetaxel and carboplatin is an active regimen in advanced non-small-cell lung cancer: A phase II study in Caucasian and Asian patients. Ann Oncol 2003;14(3):449-54.

46. Kimball P, Elswick RK, Shiffman M. Ethnicity and cytokine production gauge response of patients with hepatitis $\mathrm{C}$ to interferon-alpha therapy. J Med Virol 2001;65(3):510-6.

47. De Maria N, Colantoni A, Idilman R, Friedlander L, Harig J, Van Thiel DH. Impaired response to high-dose interferon treatment in African-Americans with chronic hepatitis C. Hepatogastroenterology 2002;49(45):788-92.

48. Goran MI, Bergman RN, Cruz ML, Watanabe R. Insulin resistance and associated compensatory responses in African-American and Hispanic children. Diabetes Care 2002;25(12):2184-90.

49. Bhatia S, Sather HN, Heerema NA, Trigg ME, Gaynon PS, Robison LL. Racial and ethnic differences in survival of children with acute lymphoblastic leukemia. Blood 2002;100(6):1957-64.

50. Pollock BH, DeBaun MR, Camitta BM, Shuster JJ, Ravindranath Y, Pullen DJ, et al. Racial differences in the survival of childhood B-precursor acute lymphoblastic leukemia: A Pediatric Oncology Group Study. J Clin Oncol 2000;18(4):813-23.

51. Kadan-Lottick NS, Ness KK, Bhatia S, Gurney JG. Survival variability by race and ethnicity in childhood acute lymphoblastic leukemia. JAMA 2003;290(15):2008-14

52. Ibrahim R. Diabetes mellitus Type II: Review of oral treatment options.
Int J Pharm Pharm Sci 2010;2:21-30.

53. Gerich J, Raskin P, Jean-Louis L, Purkayastha D, Baron MA. PRESERVE-beta: Two-year efficacy and safety of initial combination therapy with nateglinide or glyburide plus metformin. Diabetes Care 2005;28(9):2093-9.

54. Rosenstock J, Zinman B, Murphy LJ, Clement SC, Moore P, Bowering $\mathrm{CK}$, et al. Inhaled insulin improves glycemic control when substituted for or added to oral combination therapy in Type 2 diabetes: A randomized, controlled trial. Ann Intern Med 2005;143(8):549-58.

55. Bailey CJ, Bagdonas A, Rubes J, McMorn SO, Donaldson J, Biswas N, et al. Rosiglitazone/metformin fixed-dose combination compared with uptitrated metformin alone in Type 2 diabetes mellitus: A 24-week, multicenter, randomized, double-blind, parallel-group study. Clin Ther 2005;27(10):1548-61.

56. Heart Failure Society of America, Lindenfeld J, Albert NM, Boehmer JP, Collins SP, Ezekowitz JA, et al. HFSA 2010 comprehensive heart failure practice guideline. J Card Fail 2010;16(6):e1-194.

57. Hunt SA, Abraham WT, Chin MH, Feldman AM, Francis GS, Ganiats TG, et al. 2009 focused update incorporated into the ACC/ AHA 2005 guidelines for the diagnosis and management of heart failure in adults: A report of the american college of cardiology foundation/ american heart association task force on practice guidelines: Develop. Circulation 2009;119:e391-479.

58. Mitchell JE, Ferdinand KC, Watson KE, Wenger NK, Watkins LO, Flack JM, et al. Treatment of heart failure in African Americans - A call to action. J Natl Med Assoc 2011;103(2):86-98.

59. Maglo KN, Rubinstein J, Huang B, Ittenbach RF. BiDil in the clinic: An interdisciplinary investigation of physicians' prescription patterns of a race-based therapy. AJOB Empir Bioeth 2014;5(4):37-52. 